\title{
How does China fare on the Russian market? Implications for the European Union
}

\author{
Alicia Garcia-Herrero ${ }^{\text {a,b, }}$, Jianwei $\mathrm{Xu}^{\text {a }}$ \\ a Bruegel, Brussels, Belgium \\ ${ }^{\mathrm{b}}$ Hong Kong University of Science and Technology, Hong Kong, China
}

\begin{abstract}
This paper reviews China's growing economic ties with Russia. We conclude that such ties have strengthened in terms of trade and cross border lending, but less in terms of Chinese foreign direct investment in, or portfolio flows to, Russia. Meanwhile, Europe remains Russia's largest trading partner, lender and investor. In relation to trade, China seems to have become more of a competitor for the EU on Russia's market when we appraise China's increasing export share and the increasing value added of its exports and previous empirical analysis at the product level. Increasing competition between European and Chinese exports should not be surprising as there is ample evidence that China has been moving fast up the technology ladder during the past few decades. Competition over investment and lending is more limited but the situation could change rapidly with China and Russia giving clear signs of a stronger-than-ever strategic partnership.
\end{abstract}

Keywords: trade, investment, cross-border lending, Russia, China, European Union.

JEL classification: F10, F21, F50.

\section{Introduction}

The last two decades have seen a very rapid increase in trade and lending between China and Russia. The investment relationship has remained more subdued. China dominates every aspect of the bilateral economic relationship, as a net exporter, net creditor and net investor, despite Russia having long been a richer country than China.

China and Russia are increasingly viewed as important political and economic partners, notwithstanding their past differences. However, in terms of trade and investment, economic cooperation between the two countries' remains less

\footnotetext{
* Corresponding author, E-mail address: alicia.garcia-herrero@bruegel.org
} 
intense than their diplomatic relationship, even though their formal economic interactions can be traced back to the 1700s and both shared a similar economic model, namely central planning, for a good part of the twentieth century.

China has risen very rapidly in economic terms over the past two decades since its accession to the World Trade Organization (WTO). In particular, it has become the largest exporter in the world from a very low base, surpassing Europe. In that context, it is unsurprising that Chinese goods have flooded Russia, eating into the EU's (Appendix Table A1) and the US's export shares to Russia. Beyond China's increasing economic weight, the changing global environment, including the sanctions and counter-sanctions between the West and Russia, the US-China trade war and the US-led Indo-Pacific Strategy, have helped re-orient Russia's economic relationships towards the East, with China being the largest player.

China has also become increasingly interested in its neighborhood (and beyond) with its landmark project, the Belt and Road Initiative (BRI), with a particular focus on the developing countries (Kohli et al., 2019). Among the large and increasing number of countries that participate in the BRI, Russia occupies an important position as the recipient of the largest amount of Chinese funding, mainly for energy and railway infrastructure. In particular, out of the six corridors China has announced for the BRI, several cross Russia, including the New Eurasian Land Bridge and the China-Mongolia-Russia Corridor. In addition, Russia and China have agreed to jointly build an "Ice Silk Road" along the northern sea route in the Arctic. All in all, Russia has unquestionably become an important partner in China's massive global infrastructure project plans. Russia has also proposed the concept of a Great Eurasian Partnership, which is seen as a way for the Kremlin to preserve its relationships within its neighborhood at a time of very rapid increase in Chinese influence (Köstem, 2019).

In spite of the closer interest between China and the EU in the global market, there have been only a few papers discussing its impact. In an earlier study, Garcia-Herrero and $\mathrm{Xu}$ (2016) estimate the elasticity of substitution between China and the EU in offering their goods to Russia, and find that the degree of competitiveness has been increased significantly in recent years. Using similar techniques, García-Herrero et al. (2018) analyze China and the EU's competition in Latin America. However, the existing discussion only focused on trade but few studies have extended it to the analysis of investment and finance.

In our paper, we offer a comprehensive statistical analysis summarizing China's economic role in Russia, as well as its competition with the EU in these dimensions. Our analysis suggests that China and Russia's competition has been concentrated on trade so far. Although Chinese outbound investment grew rapidly over the past years, it remains limited in Russia, especially in terms of acquisitions, and the same is true for China's outbound lending. That said, China's direct investment and lending have shown strong strategic characteristics.

For the rest of the paper, we first discuss the data and methodology of the analysis, and then offer an overview of China-Russia economic connections since 2000. In the fourth part, we further discuss the competition between China and the EU in Russia via trade, investment and lending channels. The last section concludes the paper. 


\section{Data and methodology}

To analyze the evolvement of economic relationship between China and the EU, we choose statistical analysis for the study. In particular, we use data from various sources in both EU and China to characterize its trade, investment and lending aspects.

The trade data is mainly sourced from UN Comtrade, choosing China as the report country, and Russia and the EU as the partner country. Because there is no EU-level report of the trade statistics included in UN Comtrade, and the coverage of EU member states change over time, we add up export and import for the 28 EU countries starting from the 1990s. However, for the part analysing China and EU's market share in Russia, which requires comparable statistics for their exports to Russia, we alternatively choose Russia's import information sourced from Eurostat trade database.

One important feature of recent trade development is the increasing role of value added. It differs from the traditional trade analysis as it offers a more direct link between trade and the value added for each country. There have been a number of studies arguing that China's domestic value added embedded in trade is much smaller than shown by gross trade (Koopman et al., 2012). To shed light on the value added aspect of trade, we use the OECD Tiva to unveil the value added component of China and the EU's trade relationship with Russia from 2005 to 2015.

The direct investment data is sourced from the Bank of Russia, which reports the aggregate investment, as well as cross-border direct investment data by industry and by source country for Russia. To further compare the two types of direct investment, namely mergers and acquisitions, and greenfield investment, we also use two transaction-level databases: Mergermarket and fDi Markets, for detailed analysis.

For lending, the most widely used database is the BIS cross-border lending data. However, the BIS does not report China's lending by partner countries. As such, we make an estimate by calculating China's lending as the difference between Russia's total liabilities minus the available BIS reporting country's lending to Russia. The method obviously over-estimates China's lending to the rest of the world, but the statistical error is likely to be limited as China is the biggest country covered in the rest of the world. Furthermore, given that there is strong capital control and most of China's cross-border lending is conducted by the state-owned project, we also use the AEI project finance data for an alternative measure for our estimate of China's lending to Russia.

\section{An overview of the China-Russia economic history}

Although strategic cooperation between China and Russia can be traced back to the seventeenth century, their economic interactions have been less prominent for most of their history (Lotspeich, 2006). Trade, lending and to a lesser extent investment flows between China and Russia, only became relevant from the mid-1980s when the two countries started to transition from planned to market economies. In the following sections, we offer a brief account of economic bilateral relations since then. 


\subsection{Trade}

In the 1990s, Russia-China trade was relatively small (Fig. 1) but even then, China was more important for Russia than Russia for China. According to Chinese statistics, Russia only took 1 percent of China's total exports and provided 2.8 percent of China's total imports, while according to Russian statistics, China took 4.7 percent of Russia's exports and provided 3.3 percent of Russia's imports. Other than the limited nature of trade between the countries, certainly compared to today, it is important to note that Russia maintained a moderate trade surplus with China during the 1990s (Fig. 2). ${ }^{1}$

During this period, because of its clearly more advanced position in industrial production, Russia was able to export to China a wide range of goods including raw materials, especially oil and gas, iron, steel, fertilizer and non-ferrous metals, and capital-intensive products such as transport equipment and road vehicles (Fig. 3b). China's exports to Russia, during the same decade, specialized in traditional labor-intensive products, especially textiles (Fig. 3a).

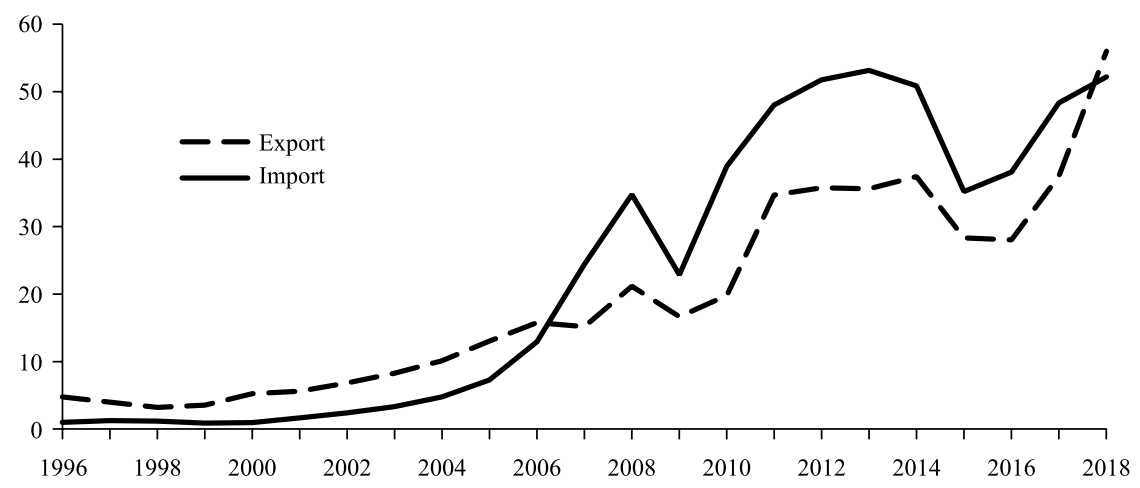

Fig. 1. Russia's exports to and imports from China (USD billion).

Sources: UN Comtrade; Russian reported data.

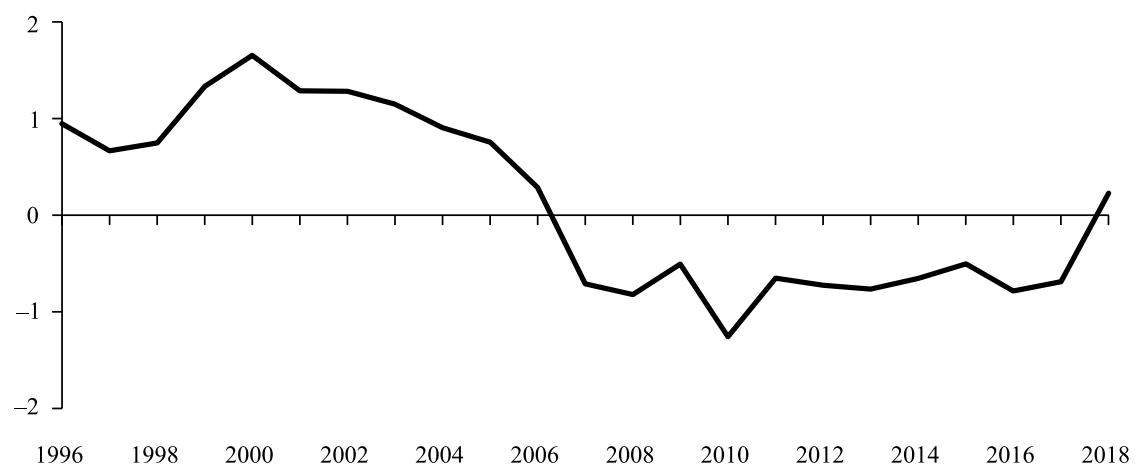

Fig. 2. Russia's trade balance with China (\% of Russian GDP).

Sources: Natixis; UN Comtrade.

\footnotetext{
1 In particular, between 1992 to 2000, Russia's average annual trade surplus with China increased from USD 1.2 billion to USD 3.5 billion.
} 

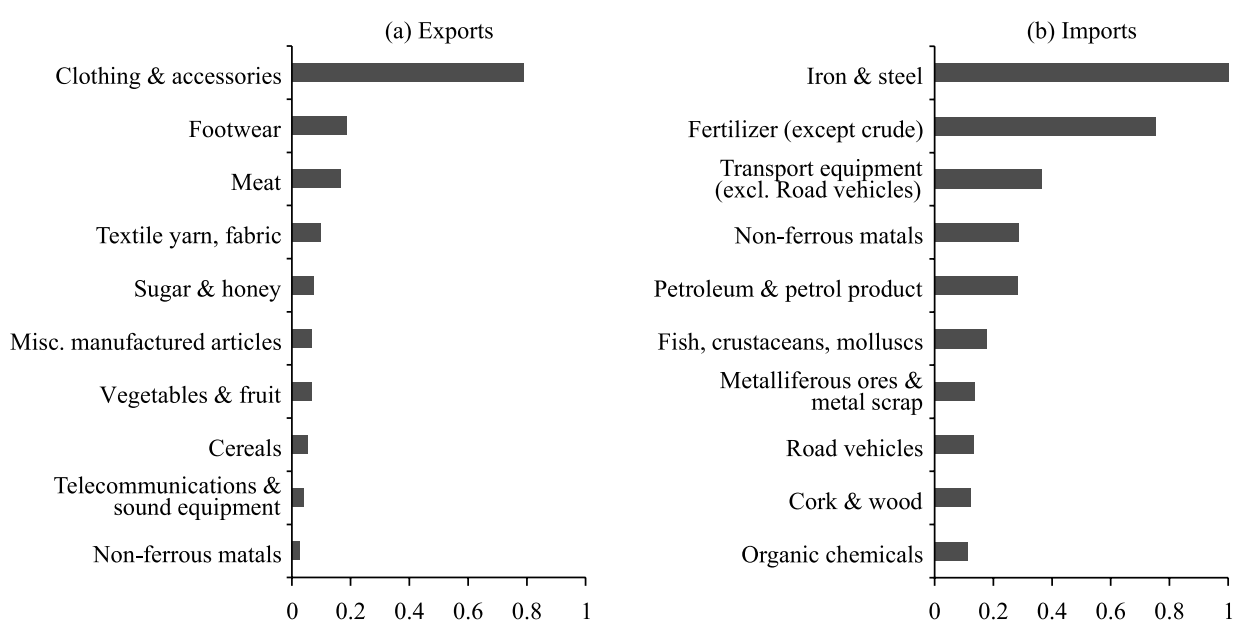

Fig. 3. China top 10 exports to and imports from Russia, 1992-2000 (annual average, USD billion).

Sources: Natixis; UN Comtrade and by 2-Digit Standard International Trade Classification (SITC) Rev. 3.

The key moment for China's economic development, in the context of its opening-up policy, was its accession to the WTO in 2000. Since then, China has witnessed miraculous growth while Russia's economy has stagnated, especially in years of weak commodity prices. In fact, by the early 2000s, China's economy was four times larger than Russia's. Two decades later, China's GDP has reached USD 13 trillion while Russia's has remained relatively flat and is now USD 1.6 trillion. In addition to their increasingly unbalanced economic sizes, China's easier access to export markets through its membership of the WTO, and very large inward FDI into the manufacturing sector, have contributed to China's massive increase of exports to Russia. At the same time, Russia's exports to China have grown at a much slower pace, pushing Russia's bilateral trade balance with China to a deficit of around USD 1.2 billion on average from 2001 to 2014, accounting for approximately 1.2 percent of Russia's GDP but less than 0.03 percent of China's GDP. Russia's trade deficit with China continued until the drastic reversion in 2018 to a surplus of more than USD 15 billion, because of China's massive imports of oil, contributing 64 percent of the increase in imports.

Generally, China has become more important for Russia since 2000, moving from the latter's sixth largest trading partner in 2000 to its top trading partner in 2018. In other words, China has now surpassed Germany with a trade share of 15.5 percent compared to 9.3 percent for Germany. While the EU is still much more important than China, with a share of 44 percent of Russia's total trade, China is reducing the gap year after year. In turn, Russia has become less important for China since 2007 and only accounted for 0.8 percent of China's total trade (the sum of exports and imports) in 2018. However, the recent large increase in China's oil imports from Russia, if sustained, will make Russia much more important strategically for China.

Going beyond gross trade to value added, China has significantly moved up the technology ladder since its accession to the WTO. Most of its exports to Russia are now at a higher technology level than in the past, including machinery and transport equipment, while the share of labor-intensive goods has declined 
(especially textiles and footwear). These higher-end goods started to show up in China's top 10 list of goods exported to Russia right after China's WTO accession (2001 to 2007), though remaining only a small share of the total (Fig. 4a). Since then, their share has ballooned (Fig. 5a). At the other end of the spectrum, Russian exports to China have continued to focus on raw materials, especially oil and gas (Figs. 4b and 5b). Although some capital-intensive goods remain among Russia's top 10 exports to China, their importance has declined significantly. This is especially the case with the automobile sector, which was the eighth largest export category for Russia from before 2000, but dropped out of the top 10 list after 2000. In turn, China has gradually become an important supplier of automobiles to Russia (see Fig. 5a).
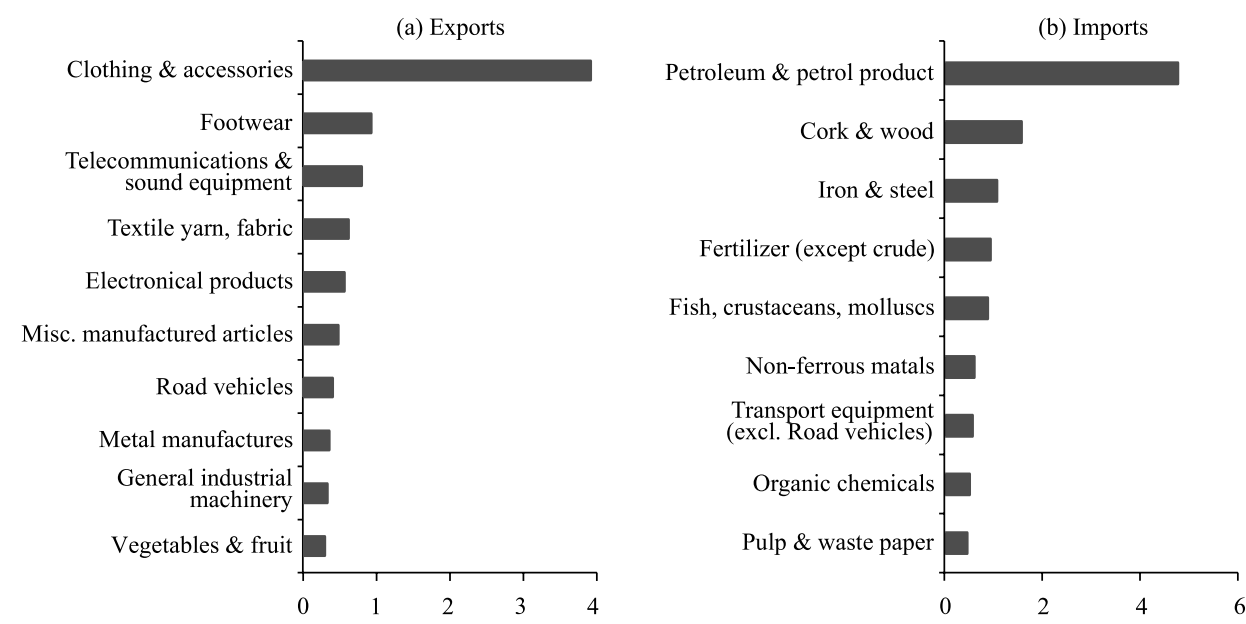

Fig. 4. China top 10 imports from and exports to Russia, 2001-2007 (annual average, USD billion).

Source: Natixis; UN Comtrade and by 2-Digit Standard International Trade Classification (SITC) Rev. 3.
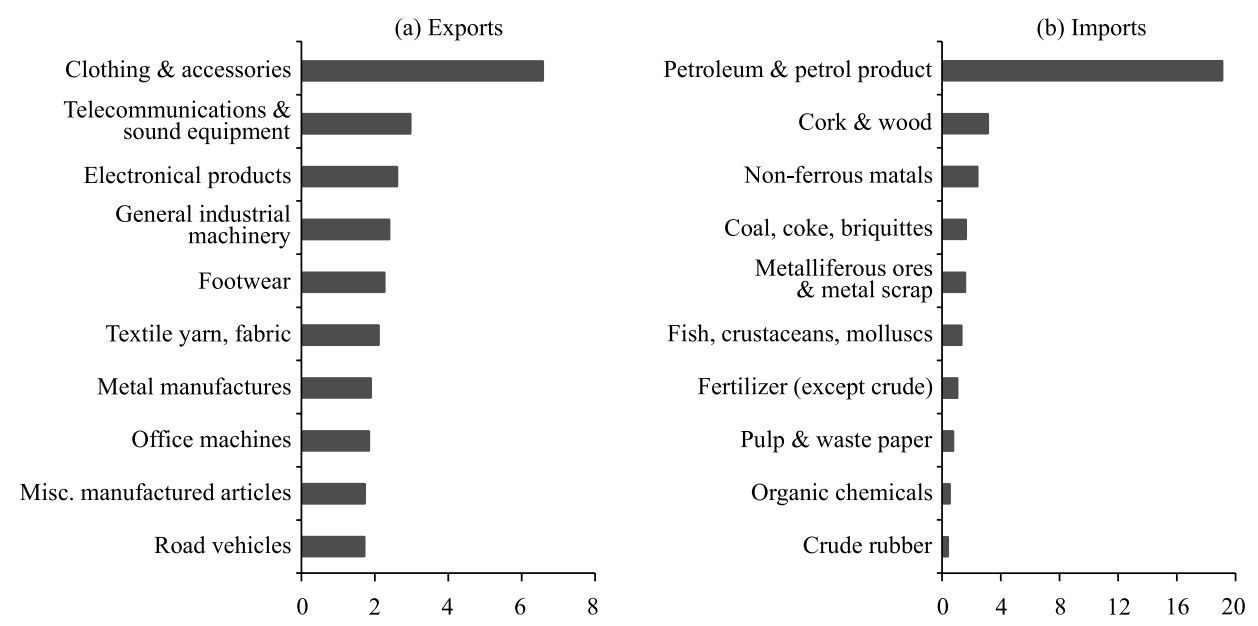

Fig. 5. China top 10 imports from and exports to Russia, 2008-2017 (annual average, USD billion).

Source: Natixis; UN Comtrade and by 2-Digit Standard International Trade Classification (SITC) Rev. 3. 


\subsection{Lending and investment}

In the last few years, the pace of Chinese outbound investment and lending has accelerated because of increasingly low domestic returns and the need for international diversification. Nevertheless, the amount of Chinese FDI going to Russia continues to be moderate and has actually come close to zero since the peak in 2014 (Fig. 6). The stock of China's direct investment in Russia is tiny compared to that of Europe (Fig. 7).

Admittedly, the direct investment statistics are always blurred, because a large share of China's outward FDI is intermediated through offshore centers such as Hong Kong (60 percent of China's total outward FDI is parked in Hong Kong temporarily). In other words, it is quite likely that China's FDI in Russia is underestimated. As a complement to the official data, we also use the transactionlevel database provided by fDi Markets (for greenfield data) and Mergermarket (for merger and acquisition data) to analyze China's direct investment influence in Russia. The sum of the two yields a significantly larger flow figure of USD 7.7 billion in 2017, though this is still significantly smaller than FDI from the EU-28 reported in official data, e.g., USD 15.1 billion.

As for the type of direct investment, China seems to have opted for more greenfield investment rather than mergers and acquisitions (M\&A). In fact, Chinese greenfield investment in Russia has significantly increased since 2012 (Fig. 8). In three of the five years from 2012 to 2017, the value of Chinese greenfield investment in Russia amounted to more than half of its greenfield investment in

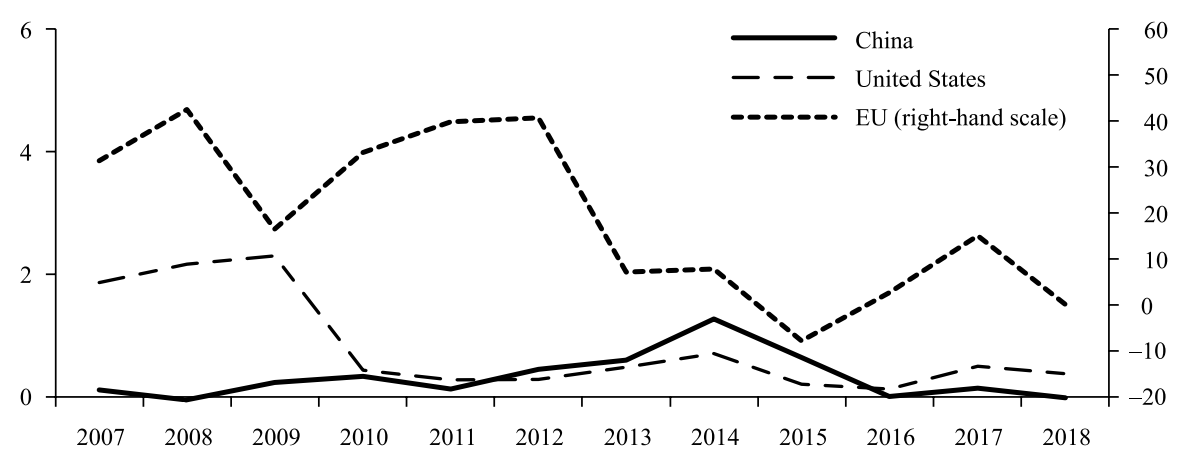

Fig. 6. China's FDI flow into Russia, 2014-2018 (USD billion).

Source: Bank of Russia.

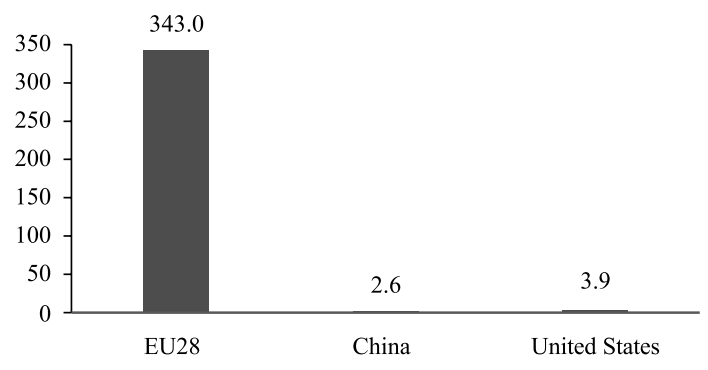

Fig. 7. FDI position in Russia, 2018 (USD billion). 


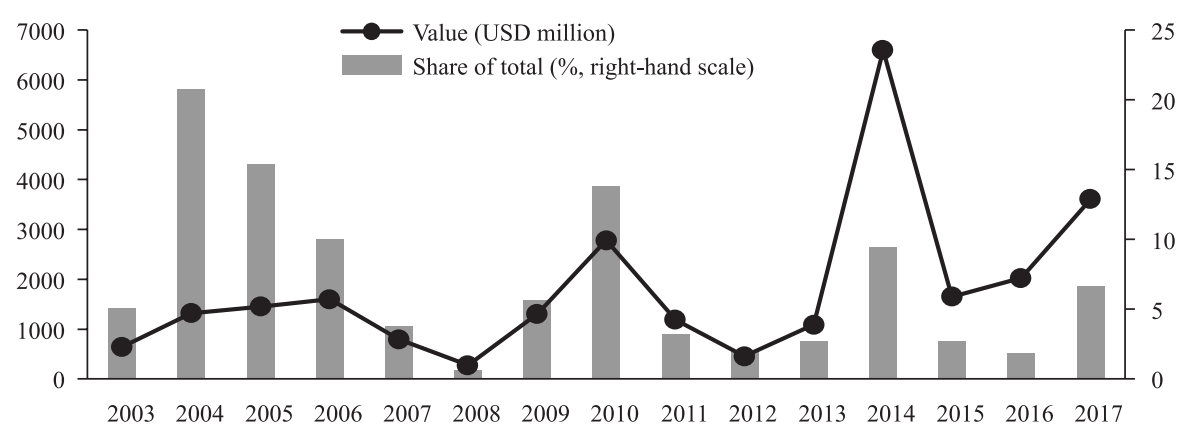

Fig. 8. Chinese greenfield investment in Russia.

Source: fDi Market.

Table 1

Share in China's total outbound greenfield investment (\%).

\begin{tabular}{llll}
\hline Year & EU-28 & Russia & US \\
\hline 2013 & 16.2 & 2.7 & 25.4 \\
2014 & 13.5 & 9.4 & 13.0 \\
2015 & 4.0 & 2.7 & 7.2 \\
2016 & 10.4 & 1.8 & 7.5 \\
2017 & 11.1 & 6.7 & 11.8 \\
\hline
\end{tabular}

Source: fDi Markets.

the EU-28 and even the US (Table 1). In other words, given Russia's relatively small economic size, the scale otf Chinese greenfield investment is quite impressive. An industry breakdown of this investment further indicates that China is focusing on Russia's traditional comparative advantages, namely the industrial and automobile sectors, and raw materials such as oil, metal and coal.

China's enthusiasm for investment in Russia is less prominent when acquiring companies. For most of the past six years, Russia has contributed less than 4 percent of China's overall outbound M\&A. Furthermore, there were hardly any acquisitions in 2017 and 2018. Interestingly, though, 2019 has seen a huge rise in activity because of a very large transaction, namely China National Petroleum Corporation and China National Offshore Oil Corporation's acquisition of a 20 percent share of Novatek's Arctic LNG 2. This deal alone amounted to 16.7 percent of China's total outbound M\&A in the first half of 2019 (Fig. 9 and Table 2). Because of China's sharp increase in oil imports from Russia, it confirms that China is viewing Russia as an important strategic partner (Wittmann, 2019).

In terms of lending, especially project finance, China has rapidly become more influential in Russia. According to the American Enterprise Institute statistics, there were hardly any Russian projects financed by China before 2009, but such activities accelerated thereafter and peaked in 2017, with USD 6.34 billion in projects built and financed by China. Russia now accounts for more than 6 percent of China's total external project finance value - a share much higher than Russia's trade share. Since the peak year of 2017, however, Chinese project finance in Russia has moderated. The key sectors for lending reflect China's comparative advantage, namely raw materials (including chemicals, metals and energy), and also China's expertise, with project finance also covering infrastructure and real estate (Fig. 10). 


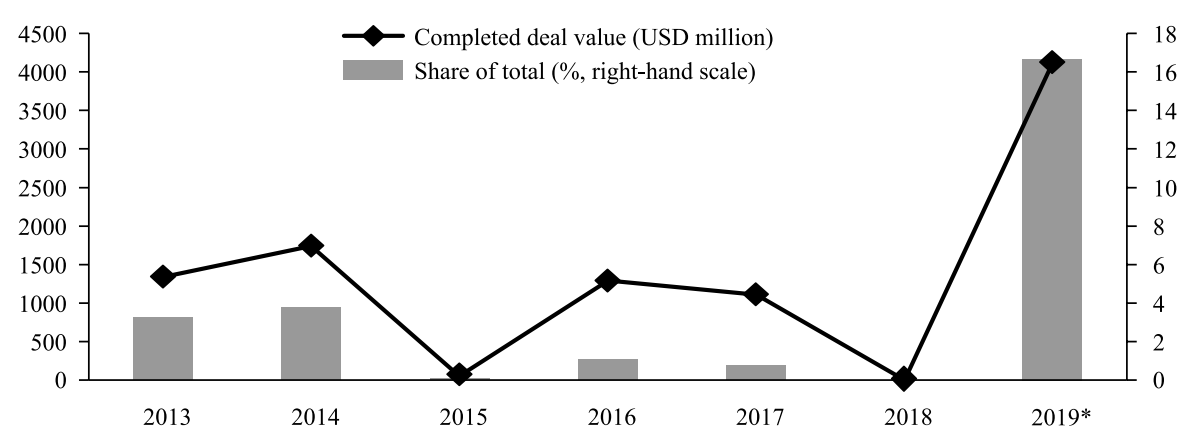

Fig. 9. Chinese M\&A in Russia.

* Forecast based on the deal value of the first half of the year.

Source: Bruegel based on Mergermarket and American Enterprise Institute.

Table 2

Share of China's completed M\&A (by deal value, \%).

\begin{tabular}{lccc}
\hline Year & EU-28 & Russia & US \\
\hline 2013 & 7.7 & 3.3 & 34.1 \\
2014 & 47.5 & 3.8 & 12.0 \\
2015 & 40.8 & 0.1 & 17.4 \\
2016 & 33.0 & 1.1 & 32.7 \\
2017 & 25.6 & 0.7 & 21.8 \\
2018 & 47.4 & 0.0 & 5.9 \\
2019 H1 & 42.8 & 16.7 & 11.7 \\
\hline
\end{tabular}

Source: Bruegel based on Mergermarket and American Enterprise Institute.
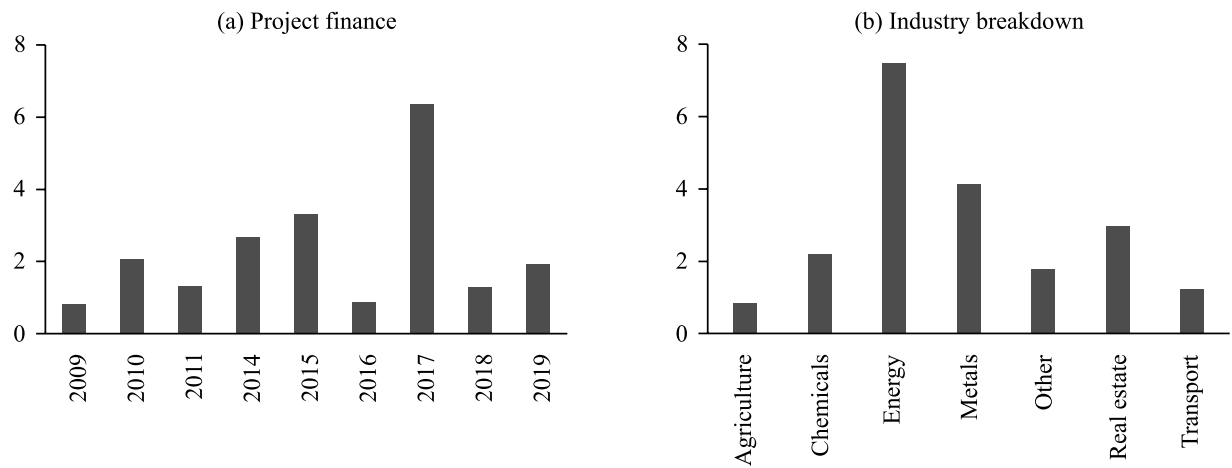

Fig. 10. Chinese project finance in Russia and its industry breakdown (USD billion).

Source: American Enterprise Institute.

\section{To what extent do China and the EU compete on the Russian market?}

\subsection{For trade: increasingly}

The surge in Chinese trade with Russia clearly poses challenges for European firms. In 1995, the EU accounted for 40 percent of Russia's total imports and that share went up to 53 percent in 2002 and down again more recently to about the level it started at in 1995, namely 40 percent. However, China's share of Russia's imports has increased steadily from less than 3 percent to 21 percent. 
(a) China's exports to Russia

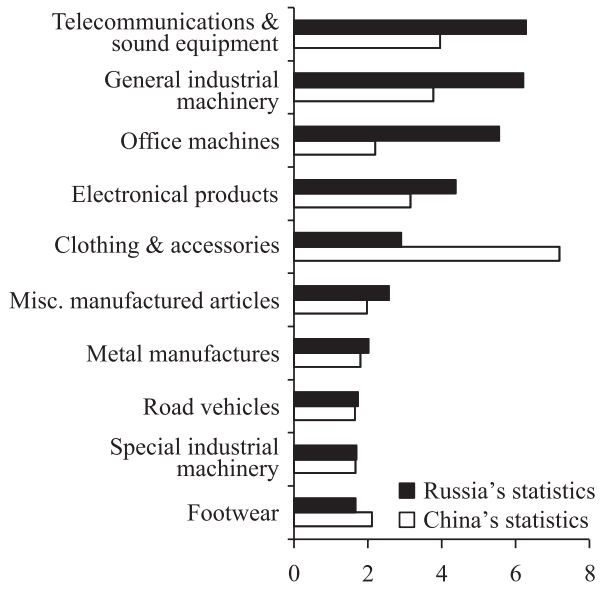

(b) EU's exports to Russia

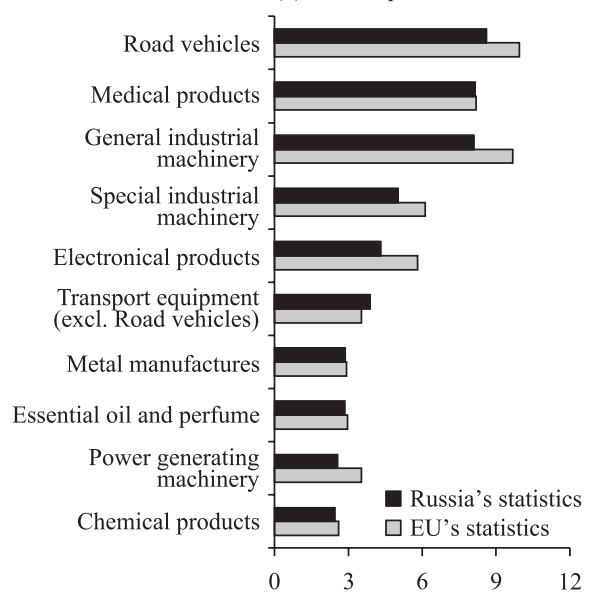

Fig. 11. China's and EU's exports to Russia, 2017 (USD billion).

Sources: UN Comtrade and by 2-Digit Standard International Trade Classification (SITC) Rev. 3.

In terms of sectors, half of the Chinese and EU top 10 most exported goods to Russia overlap, including electrical products, general and special machinery and road vehicles (Fig. 11). According to Russia's own statistics, the total value of the five overlapping groups of products imported from China reached USD 16.01 billion in 2017, already more than half of the equivalent imports from the EU-28 (USD 28.92 billion). Another important example is telecommunications and sound equipment, which is China's top exported product category to Russia but is missing from the EU's top 10 list of exports to Russia.

Garcia-Herrero and $\mathrm{Xu}$ (2016) confirmed quantitatively that Chinese exports are increasingly relevant substitutes for EU exports on the Russian market, especially in capital-intensive sectors such as electronic products. That said, China's export growth over the past two decades is concentrated on the processing trade, or the business activity of importing parts and components from abroad for processing or assembly, with the finished goods re-exported to the rest of the world. However, China has been moving up the ladder by incorporating a larger share of domestic production in the final goods it exports (Fig. 12). This is also true for China's exports to Russia, with average domestic value added increasing from slightly above 75 percent to over 80 percent from 2005 to 2015 . Meanwhile, the domestic value added of EU exports to Russia is still higher than China's, but has remained stagnant since 2005 and has even dropped more recently $^{2}$ (Fig. 13). This evidence suggests that an increase in China-Russia economic cooperation could have a negative impact on European exports, which is confirmed by the simulation exercise carried out by Garcia-Herrero and $\mathrm{Xu}$ (2016).

All in all, the increase in China's market share in Russia that we find when looking at gross trade data (Fig. 14) is confirmed when controlling for the value added of European versus Chinese exports (Fig. 15). This is in line with our

\footnotetext{
2 Our report of domestic value added in exports for the EU treats intra-European trade as domestic based on the data from OECD (TIVA).
} 


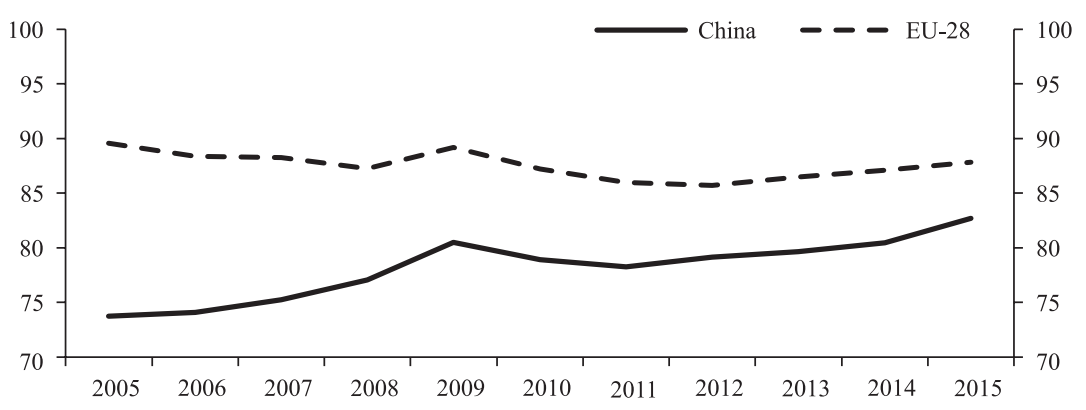

Fig. 12. Domestic value added in China and EU gross exports to the world, 2005-2015 (\%). Sources: Natixis; OECD Tiva.

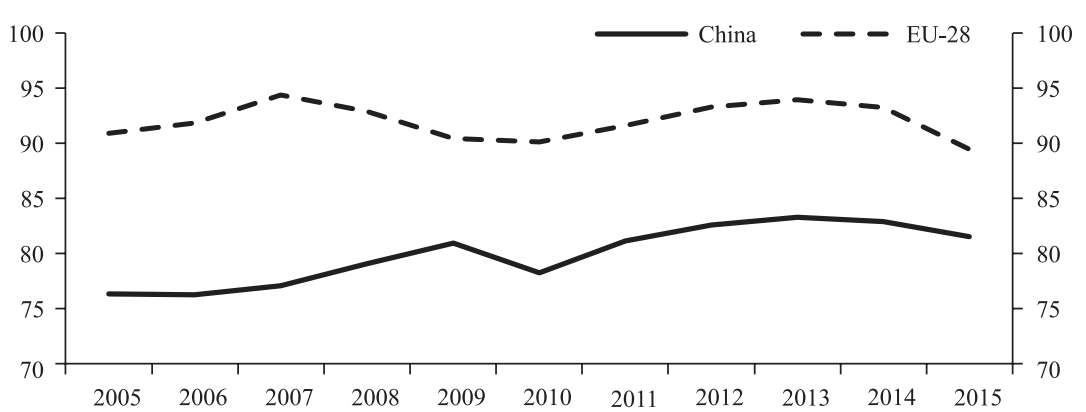

Fig. 13. Domestic value added embedded in China and EU gross exports to Russia, 2005-2015 (\%). Source: OECD Tiva.

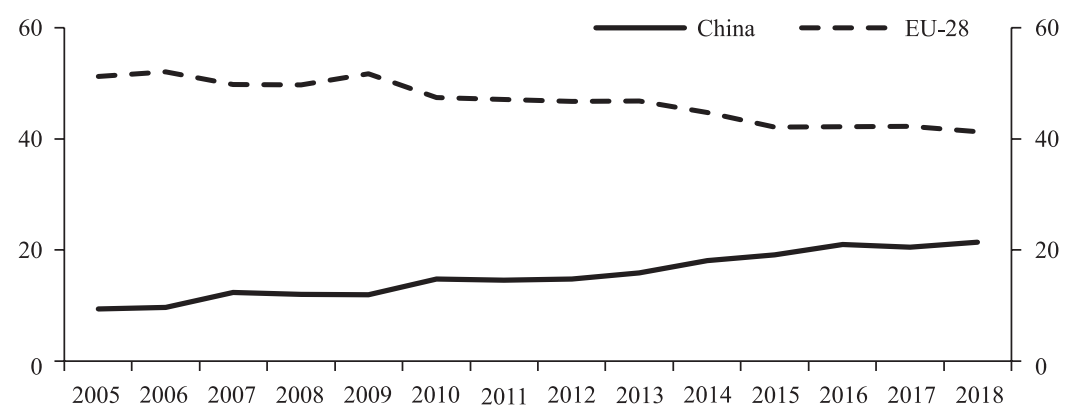

Fig. 14. EU-28 and Chinese market shares in Russia, 2005-2018 (\%).

Sources: Natixis; UNCTAD.

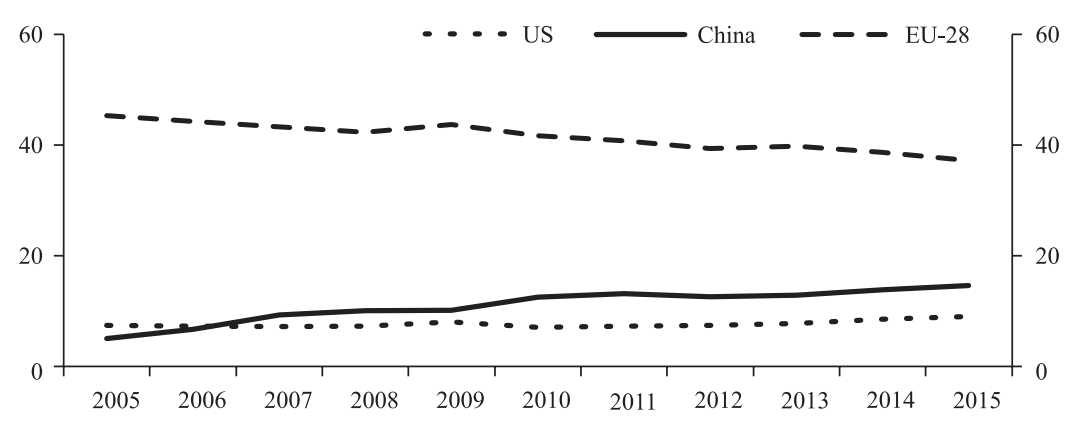

Fig. 15. Share of the value added embedded in Russia's final demand, 2005-2015 (\%). 
finding that the domestic share of China's value added exports to Russia has increased very steadily (see Fig. 13), and is also in line with the changes in the top 10 Chinese products exported to Russia.

\subsection{Not much competition for investment}

China-EU competition in the field of investment is much less pronounced. As section 2 showed, while Chinese investment in the world has surged, its exposure in Russia is limited and remains much less than the EU's. For example, the Chinese FDI flow into Russia was only USD 140 million in 2017 (only 0.1 percent of Russia's GDP), and the value even dropped into negative territory, to minus USD 13 million, in 2018. Meanwhile, the EU-28 total FDI flow into Russia reached USD 2.6 billion and USD 15 billion in 2017 and 2018, accounting for 2.1 percent and 11.6 percent of Russia’s GDP respectively (Fig. 16).

In addition, the industry focus of Chinese investment has been very different to that of the EU-28. In 2018, the biggest target of Chinese direct investment in Russia was the real estate sector, with the financial and manufacturing sectors attracting less Chinese investment. EU companies have much broader interests in manufacturing and a number of service sectors including wholesale and retail (Fig. 17).

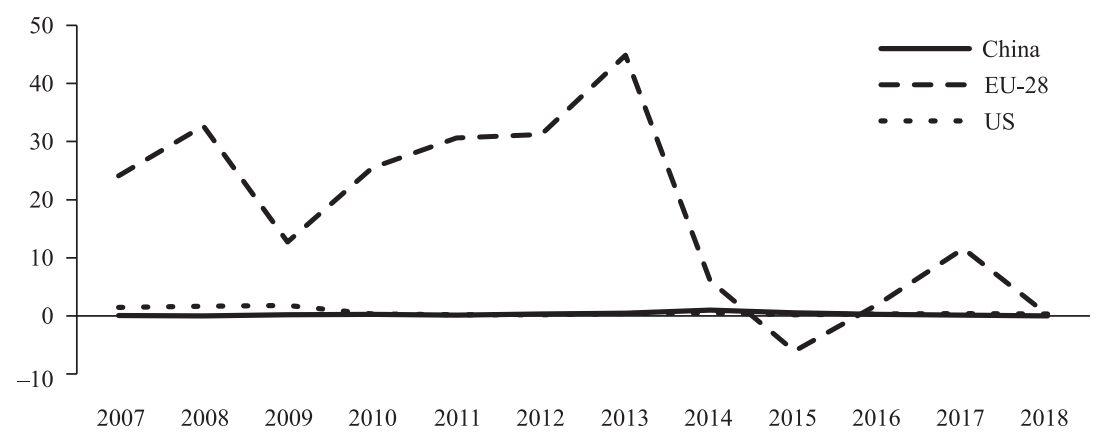

Fig. 16. FDI flow into Russia (USD billion).

Source: Bank of Russia.

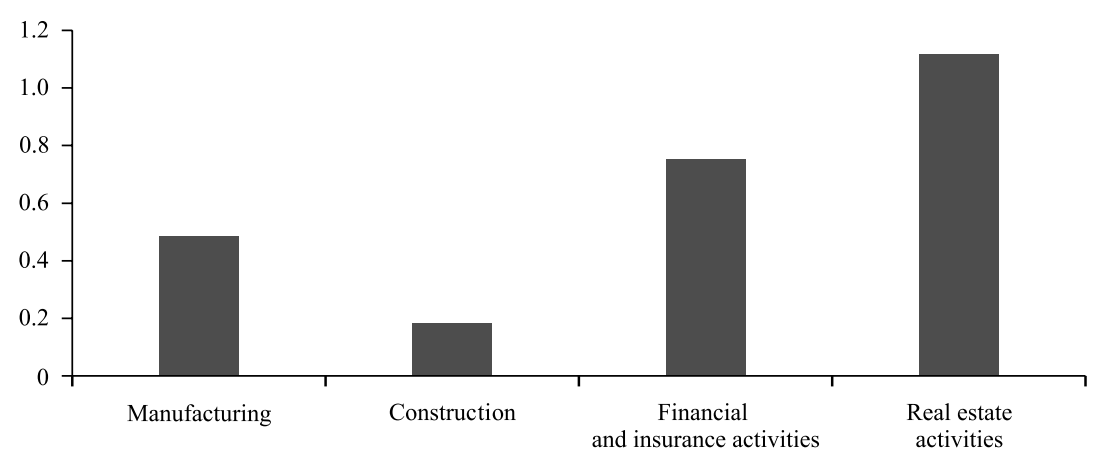

Fig. 17. Industry breakdown of the EU's FDI position in Russia, 2018 (USD billion).

Note: Only sectors with FDI larger than 0.1 billion are reported.

Source: Bank of Russia. 


\subsection{Financial competition is starting}

Following the annexation of Crimea by Russia, the financial role the EU played in Russia was taken over by China because of the enforcement of sanctions by Western countries in 2014. Indeed, there was a sharp decline in the EU's financial claims in Russia in 2016, only two years after the sanctions were imposed. In the meantime, China has continued to support projects developed in Russia, as shown by the steady increase in Chinese project finance.

While the trend is clear, the EU still has a much larger financial exposure than China in Russia. First, EU portfolio investment in Russia is clearly larger than China's. As for bank lending, while there are no official statistics on the role of Chinese banks as cross-border lenders, an upper limit (including all the undisclosed countries in the Bank for International Settlements crossborder lending statistics) indicates that China could be equal to as much as one-third of the EU-28's lending position in Russia (Fig. 18). Chinese project finance, while increasing, still does not equal even one third of the EU's lending flows into Russia. In fact, according to the American Enterprise Institute,

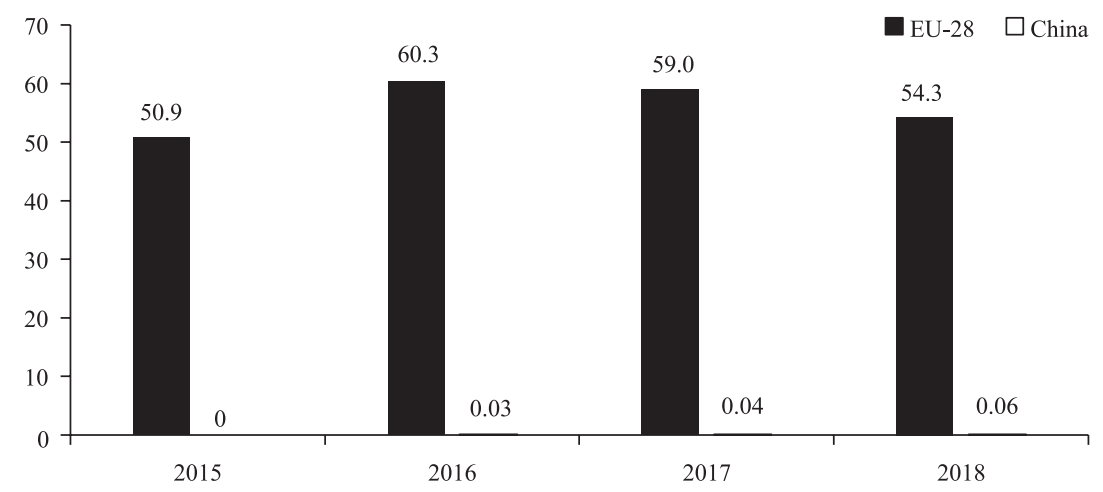

Fig. 18. Portfolio investment assets (sum of equity and debt) of Russia (USD billion). Source: Bank for International Settlements.

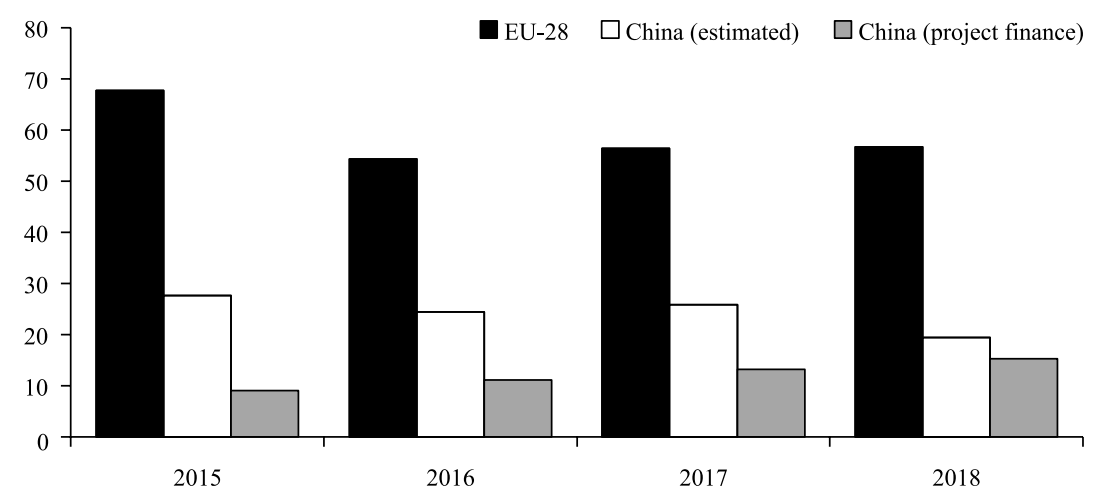

Fig. 19. Comparison of EU and Chinese lending position to Russia (USD billion).

Note: Cross-border lending data was estimated as the difference between Russia's total liabilities minus the available BIS reporting country's lending to Russia .

Source: Cross-border lending data from Bank for International Settlements, and project data from the construction projects collected by the American Enterprise Institute. 
the cumulative sum value of Chinese project finance in Russia since 2005 was USD 18.7 billion in 2018. For the EU countries, total cross-border lending for the 14 largest EU economies shows accumulated claims in Russia of about USD 57 billion in 2018 (Fig. 19). EU project finance data was unfortunately not available to us.

\section{Conclusions}

We have reviewed China's growing economic influence in Russia and compared it with that of Europe for the key aspects of economic relations, namely trade, investment and lending. It seems clear that Europe remains Russia's largest trading partner, lender and investor, but China is catching up quickly, especially on trade and project finance. However, Chinese investment in Russia remains limited, especially in terms of acquisitions. Chinese greenfield investment is much more notable. Furthermore, China's acquisition of a stake in one of Russia's most strategic companies, Novotek, and China's massive increase in Russian oil imports in 2019, seem to indicate that Russia is becoming a major strategic partner for China.

Competition between the EU and China on the Russian market shows up most clearly in trade data, with the EU losing market share and China ramping up the value added of its exports to Russia. This is much less the case for investment and is only starting for cross-border lending, mainly in the project finance field.

Finally, and more specifically on trade competition, our estimates of the increased share of Chinese value added going into Russia, with a stagnant share for Europe, confirms our earlier empirical findings based on industry level data (see Garcia-Herrero and $\mathrm{Xu}, 2016$ ).

\section{References}

Garcia-Herrero, A., \& Xu, J. (2016). The China-Russia trade relationship and its impact on Europe. Bruegel Working Paper, No. 4. Available at http://bruegel.org/wp-content/uploads/ 2016/07/WP-2016_04-180716.pdf

García-Herrero, A., Marbach, T., \& Xu, J. (2018). European and Chinese trade competition in third markets: The case of Latin America. Bruegel Working Paper, No. 6. Available at https:// bruegel.org/wp-content/uploads/2018/06/WP-2018-06_-060618.pdf

Kohli, H. S., Linn, J. F., \& Zucker, L. M. (Eds.) (2019). China's Belt and Road Initiative: Potential transformation of Central Asia and the South Caucasus. Sage Publications.

Koopman, R., Wang, Zhi, \& Wei, Shang-Jin (2012). Estimating domestic content in exports when processing trade is pervasive. Journal of Development Economics, 99 (1), 178-189. https:// doi.org/10.1016/j.jdeveco.2011.12.004

Köstem, S. (2019). Russia's search for a greater Eurasia: Origins, promises, and prospects. Kennan Cable, No. 40, Kennan Institute. Available at https:/www.wilsoncenter.org/sites/default/files/ kennan_cable_no._40.pdf

Lotspeich, R. (2006). Perspectives on the economic relations between China and Russia. Journal of Contemporary Asia, 36 (1), 48-74. https://doi.org/10.1080/00472330680000041

Wittmann, H.-J. (2019). Russland und China bauen strategische Zusammenarbeit weiter aus. Available at https:/www.gtai.de/gtai-de/trade/branchen/branchenbericht/russland/russlandund-china-bauen-strategische-zusammenarbeit-aus-156106 


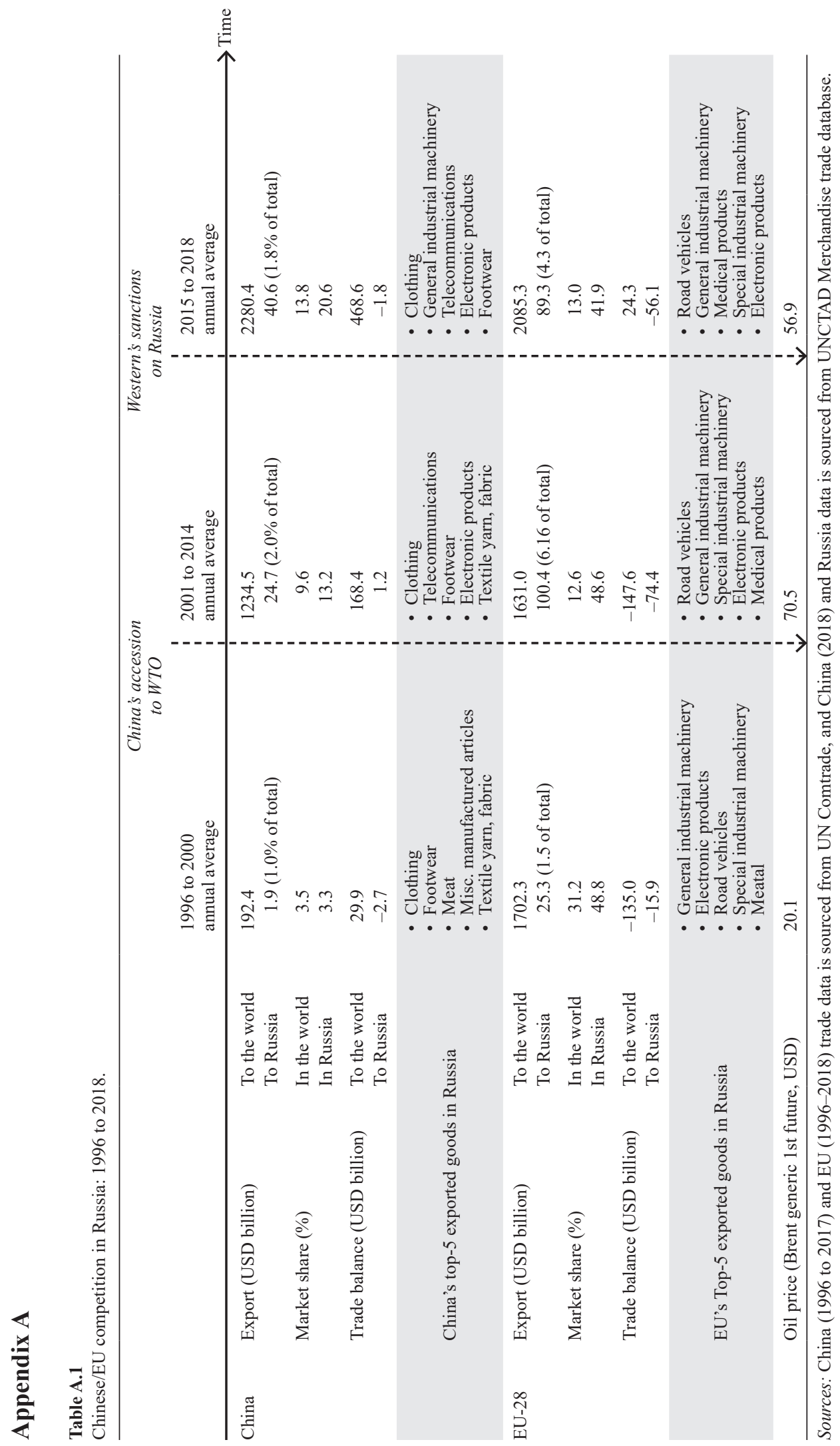

